\title{
A Research on the Development of Innovative Mathematics Teaching in Higher Education
}

\author{
Xiao Xiaonan \\ Xiamen University TanKah Kee College \\ Zhangzhou, Fujian, China \\ xiaoxn@xujc.com
}

\begin{abstract}
The teaching of university mathematics course is known as the most challenging and difficult subject among all the science, engineering, and economics college courses. With the continuous advancement and popularization of higher education in China, there is a big problem in the construction and reform of the advanced mathematics course at independent colleges brought by the contradiction between students' poor quality in many newly established independent colleges and increasingly demand from employers. Facing the new challenge of talent training, this article discusses how to "innovate education" in depth. It has to be based on the teaching of advanced mathematics course and edge of scientific research to carry out various kinds of intensive development, research and reform of teaching innovation in advanced mathematics. It calls for a breakthrough of traditional teaching modes, which may continuously explore and deepen the effective breakthrough of education in the reform and innovation of teaching in advanced mathematics. The goal is to establish an exemplary, "quality project of advanced mathematics teaching" among independent colleges in the 21st century and to explore practical and effective ways of development.
\end{abstract}

Keywords-The teaching of advanced mathematics; Reform and innovation of education; The effective breakthrough; Innovate education; Intensive development

\section{INTRODUCTION}

The ministry of education has made several suggestions on further deepening the reform of undergraduate education to improve the teaching quality on a comprehensive scale. The ministry of education clearly pointed out the directions of education reform in wholly deepening and improving the quality of undergraduate teaching in higher education. Facing the challenge of fostering new talents in the new century, we must constantly deepen the innovative quality education, moves forward to emancipate the mindset, transform our educational concept, and carry out multifaceted education research to reform and innovate education to cultivate more allaround talents for our country.

\section{BUILDING A HIGH QUALITY CURRICULUM AND Creating A Quality Project in Advanced Mathematics TEACHING}

The advanced mathematics is an important public basic course in all kinds of science and engineering, economics class colleges. It is called the hard nut. Especially for students at new independent colleges, there is a big problem that the construction and reform in the advanced mathematics course and the contradiction between student's poor quality since the enrollment expansion and increasingly demanding from employers. Facing this difficult problem, new challenges for talent cultivation and the urgent task for us to cultivate high quality innovative compound talents as soon as possible, in the multi-year process of advanced mathematics teaching, our math teacher deeply realized that in order to achieve this goal that we cannot limited by the ready-made knowledge on the books, what is more, combine with the development of modern science and technology, constantly update the teaching contents, further expand the thinking knowledge, improve teaching methods, dare to break through, dare to innovate. At the same time of grasping the quality education, we stick to grasp education in reform and innovation, integrate the students' comprehensive innovation quality into the whole teaching process. We should pay attention to the students' mastery of modern scientific knowledge and cultivate students' ability of innovation and quality. Only in this way can students be trained into high - quality compound talents who adapting to current information society requirements. To do this, in recent years of the construction and reform in advanced mathematics courses , we focus on the theme of "innovation education", carry out various kinds of intensive development, research and reform of teaching innovation in advanced mathematics, break through the traditional teaching mode, aim to stimulate constantly students' comprehensive innovation consciousness and innovation ability, always base on the frontier of teaching and research in advanced mathematics curriculum, stand at a new start and new height, update teaching content, actively explore the open teaching modes and ways to improve students' quality comprehensively, grasp advanced mathematics courses construction to effective breakthrough, which can be seen as a forward-looking, innovative, pioneering, scientific, rigorous and applicable, constantly discuss in-depth innovative ideas and means of teaching reform in advanced mathematics, integrate the development of this subject and the latest 
knowledge into the construction of high-quality courses, success complete a series of teaching reform and practice that have the characteristic, accord with independent schools in advanced mathematics high-quality courses by "Probability and statistics" and "advanced mathematics", improve the teaching quality of advanced mathematics at independent colleges, provides a strong guarantee for the establishment of advanced mathematics teaching quality project at independent college in the 21 st century.

\section{REFORM AND INNOVATION OF EDUCATION IN ADVANCED MATHEMATICS}

To build a demonstration independent college in the $21 \mathrm{st}$ century "the quality engineering in advanced mathematics teaching", we insist on the intensive developmental road of innovation teaching in advanced mathematics, actively explore from many aspects to effective breakthrough of Reform and innovation of education in advanced mathematics, carry out teaching research and reform in advanced mathematics in the following forms:

(1) Insist on promoting "one study, two points, three competitions" to achieve good results

"One study" is taking "research" as the link and actively carry out various forms of teaching research and teaching reform activities. In the intensive development research and reform of innovation teaching in advanced mathematics courses, aiming at the rapid growth of young teachers in our school in recent years, current situation of insufficient teaching experience, the teaching and research office actively carried out 66 thematic cooperation teaching and research activities on advanced mathematics teaching, through this "task-driven, project-driven" teaching and research activity on advanced mathematics sub-topics, it effectively promotes and enhances the teaching materials of all teachers teaching ability and level by deep researching teaching materials, accurate grasping of teaching materials, deep understanding of the teaching material. It has ensured the steady and rapid improvement of the advanced mathematics teaching quality.

"Two points" is to grasp the key and difficult points in the teaching and keep on coming up with new methods.

In the process that the teaching and research office leads all teachers to grasp "research" and strive to create advanced mathematics teaching quality curriculum, summarizes teaching essence, including "Advanced mathematics(A)key difficulties to analyze 100 lecture", "Advanced mathematics(D)key difficulties to analyze 50 lecture", "Probability statistics key difficulties to analyze 40 lecture ",Linear algebra key difficulties to analyze 30 lecture", The above "key difficulty profile" is popular with students, and become a mentor to students to learn advanced mathematics.

"Three competitions". The first competition is lecturing contest with the teacher's follow-up and strict appraisal to the lectures. Second competition, carrying out in-depth the students' innovative quality and technology skills competition at college, in order to further stimulate students' enthusiasm for learning. The third competition is a major competition organized by students to better prepare for the national competition, including China Undergraduate Mathematical Contest in Modeling, National Undergraduate Electronics Design Contest, Nation University Student Intelligent Car Race. By participating in a variety of national competitions, students with "academic dreams" and "creative dreams" have a chance to make their dreams come true.

(2) We work closely around the theme of "innovative education" and intensive development to actively explore reform and innovation of education in "six breakthroughs". Thus it thoroughly changes the conventional teaching method in the one-way knowledge dissemination in classroom and explores the creative, comprehensive teaching mode to improve the quality of students.

Reform and innovation of education in classroom teaching "six breakthroughs" namely:

1.The breakthrough in case teaching, arouse students interests and desires, 2.Break through interactive teaching, arouse students' learning initiative and participation, to improve learning effect, 3. Break through heuristic teaching, guide students step by step, and one instance to solve practical problems, 4. Break through hierarchical teaching, fully respect the student individuality, classified guidance, coaching answering questions carefully and help them to complete the study task smoothly. 5. Breakthrough innovation type teaching, based on cutting-edge, innovative thinking, constantly motivate the students' comprehensive creative thinking and innovation ability, 6. Breakthrough practical teaching, combining theory with practice, instructing students to actively participate in extracurricular scientific and technological activities, and carry out innovative study and innovation research.

(3) In the intensive development of innovative teaching in advanced mathematics, it is more effective to entitle the senior professors to lead, motivate, and help cultivate the junior faculty.

In order to improve the middle-aged and young teachers' teaching level as soon as possible, promote their rapid growth, teaching and research section take active measures for training in various forms, such as: adhere to the collective lesson preparation, actively carry out teaching workshops, and discuss the topic to people; give full play to teachers to teach, help, leading role, strengthen our professional middle-aged and young teachers training, improve guidance and teaching, task to people; actively carry out academic lectures, academic exchanges; in training, developing students' innovative thinking and abilities at the same time, teachers also expanded the research thinking, effective added teachers new research direction.

In order to teach a good lesson, we organize teachers to spend ten times the time and energy to study in deep, to study extensively, to think carefully, to try to teach many times. We take each lesson as "class quality" prepare lessons, as "demonstration class" research, as "template class" teaching, the effective guarantee from the efforts in preparing the classroom teaching quality enhances unceasingly. In the past few years, the "advanced mathematics teaching team" has been rated as the excellent teaching team of the university. 
"The teachers make progress, the school will go places; the teacher make progress, the teaching level will develop; the teacher make progress, student will get ahead". To create "advanced mathematics teaching quality engineering". It is the key that the teacher makes progress. The purpose of the study is to promote teaching. With the help of "research" to "teach" courses, "race" courses, teachers can study the teaching materials in depth. By bold reforming teaching methods, teachers improve themselves very quickly. All the teachers who have experienced "competition" say "The experience gained in this contest is more profound than the ten years of reading".

The teaching research and mathematics academic lectures are successfully held in our school. Such as, multimedia teaching research, mathematics observation research, teaching competition. Flexible and varied teaching reform activities, young teachers to practice basic skills, the old teacher fully exploits potentialities. The "research" class brings good teaching atmosphere and the "competition" class produces high-quality courses. Our mathematics teacher in several times over the years has won several outstanding teaching awards, innovative teaching method award, excellent teaching achievement award and "national education reform excellent teacher" .These honors are the successful demonstration that our college pay much attention to research course and compete course.

(4) We strive to create an innovative, open-ended, and high-quality curriculum and to further explore the intensive development in cultivating comprehensive, quality talents.

In recent years, we carry on the key construction that from the best quality courses of the university to the provincial level in the course of "probability statistics", together with creating "advanced mathematics" as a school-level quality course, actively explore the exploring type teaching mode and effective way of intensive development in improving students' quality comprehensively, further discusses the innovative ideas and means of the reform of advanced mathematics, successfully complete a series of advanced mathematics constructions that have distinction and accord with the actual of independent colleges, strongly promote the teaching quality of advanced mathematics in our school .

In the construction and reform of the provincial "probabilistic statistics" and school-level "advanced mathematics" quality courses. We closely embrace the theme of "advanced mathematics innovation education", always based on the teaching of advanced mathematics course and scientific research frontier, full use the combination of open, guided, discussion, interactive, practical style, art type to the teaching method and a series of modern teaching means. Standing at a new starting point and a new high, we grasp the foresight, innovation and path-breaking of advanced mathematics quality courses, as well as the website construction of the three-dimensional quality course system in "probability statistics" and "advanced mathematics". With the help of high quality resources sharing and teacher-student interaction exchange discussion platform that have rich and colorful content and informative, large amount of information and strong practicability, it greatly broadens the student's vision, inspires the students' interest in learning, improves the students' comprehensive quality and innovation, learning ability. It also plays a positive role in promoting and widespread impact, radiation effect for the province's exquisite course construction of advanced mathematics.

(5) We aim to scientifically fuse and crystalize high-quality materials to achieve a new breakthrough in the curriculum construction for independent colleges.

The reform in classroom teaching content is the core of classroom teaching reform and a key to solute the current students bad foundation, narrow range knowledge, not high learning enthusiasm, thinking of the single and not strong composite innovation capability at independent college. Because years of practice at independent colleges of advanced mathematics teaching, we deeply realize that advanced mathematics teaching materials of ordinary universities is not suitable for teaching and training target and we must work hard to reform the actual teaching of independent colleges.

Accordingly, in view of the independent college students' actual knowledge capacity, quality structure and our school focus on training the practical, compound and innovative talents with certain international competitiveness in the $21 \mathrm{st}$ century, teachers of advanced mathematics in the years of construction and reform of teaching practice, seriously study culture conditions, mode, knowledge ability quality structure requirements in applying innovative talents at independent colleges and survey in-depth, analyze the specific requirements of advanced mathematics courses for science and technology, economic and management, literature and history major in the college ,and based on the far-reaching influence of each professional follow-up course. Our school teachers have deeply revised and determined sustainable syllabus of curriculum, curriculum construction and teaching material construction plan in advanced mathematics to cultivate talents of independent colleges. Over the past few years, under the joint efforts of the teachers of the teaching and research department and full-school professional course teacher, we have been repeatedly discussing, modifying, teaching and other practical teaching links, organized our school excellent teachers who has many years of independent college advanced mathematics teaching experience. In the construction and reform of the high-quality courses in provincial and university-level advanced mathematics, we have carefully prepared the following teaching materials for advanced mathematics courses for the 21st century independent college: "Advanced mathematics (I)", "Advanced mathematics (part ii)", "Calculus", "Linear algebra", "New theory of probability and mathematical statistics (second edition)","Probability and statistics project analysis and problem solving instruction", "Modern information decision", "Modern numerical calculation method", "Numerical calculation method and the guidance of upper machine internship". It published by Beijing university press, highly praised and praised by experts, including Beijing university, tsinghua university, renmin university of China, xiamen university, fuzhou university, fujian normal university and other colleges and universities. Especially, it has a wide influence in independent colleges in the country and it promotes the advanced mathematics 
curriculum construction and teaching reform of independent college.

\section{The Crucial Key to Hone High-Quality Teaching, PRODUCE HIGH-QUALITY TALENT, AND OPEN THE DOOR FOR STUDENTS' COMPREHENSIVE INNOVATION ABILITY}

One of the advanced mathematics teaching in our school facing the new century practical, efficient, scientific and feasible new way of intensive development in innovation education is to break through the traditional teaching mode, "inquiry teaching" and "inquiry learning", the combination of the advanced teaching methods and teaching means in the classroom.

In teaching, we combine advanced mathematics teaching with advanced mathematics research, boldly create a new teaching mode combining "research and teaching", break through the traditional single, enclosed inbred teaching mode. Teachers through classroom teaching of open, heuristic, interactive, research type, discussion-based, dialectical type, practical style, art, guided and inspired students to carry out independent innovation study, integrate innovation education organically into the whole teaching and educating process. This research, teaching mode inspired students' study consciousness unceasingly, expanded the teachers and students to the modern international teaching and scientific research platform, made the students not only learned how to grasp the contemporary advanced knowledge of science and mathematics method, but also learned how to continuously acquire new knowledge, comprehensive research problems and analytical problemsolving skills. Through a variety of teaching channel, including indoor class and outdoor class, stimulate students' thirst for knowledge, cultivate and improve the students' comprehensive innovation quality, develop the students' comprehensive creative thinking and ability, this is one of the characteristics of advanced mathematics teaching in our school.

We should break the traditional small class teaching that imparting knowledge uniformity and independence, open big classroom, organize a variety of knowledge lectures about advanced mathematics and other sciences, expand the students' horizons of knowledge, increase the student's knowledge comprehensive, compound type, enable students to learn more, more comprehensive knowledge and quality. It is another highlight of the advanced mathematics teaching in our school to cultivate students into comprehensive innovative ability and develop comprehensive high-quality compound talents.

The "advanced mathematics teaching quality project" we created has always been based on "combining research with teaching", creating high-quality courses, writing high-quality teaching materials, making high-quality teaching and producing high-quality talents.

"Research" and "competition" makes teachers' overall quality, theoretical level and teaching level greatly improved. The effective breakthrough in reform and innovation of advanced mathematics education has made the mathematics planning series for the 21 st century colleges and universities written by our university more popular and well received by the readers.
In teaching "combining research with teaching", we effectively cultivate and develop the students' scientific research innovation ability, train the students' mathematical thinking ability and logical reasoning ability, greatly improve the students' ability of system analysis, comprehensive ability and practical ability to solve problems.

By means of grasping the effective breakthrough of reform and innovation of education in advanced mathematics, structuring a high starting point, strict requirements, reasonable structure, complementary advantages, cooperation, pragmatic, innovative, bold exploration and breakthrough teaching team, it's a strong guarantee that the curriculum of probability statistics in our school was awarded as "fujian province quality course" in 2009, and "advanced mathematics" was rated as "university-level quality courses".

\section{CREating THE INNOVATIVE TEACHING MODEL OF} "Quality Project OF AdVANCED MATHEMATICS TEACHING"

(1) To draw on "one study, two points, three competitions," we explore the effective breakthrough in reform and innovation of education with intensive development. It is the most relevant to the current advanced education popularization, the form of novel teaching research new topic in creating independent college "advanced mathematics teaching quality engineering" project. It is a sustainable development green channel that is "practical, tapping potential, a small amount of investment, saving money, widely beneficial and productive" in improving the teaching quality of independent colleges. The results of this teaching can also be applied to the construction and reform of other disciplines and be worth promoting.

(2) Facilitating teaching through research and the integration of research and teaching is a very effective way of connecting with the world, deepening the cutting-edge teaching reform, rapidly improving the overall quality of teachers and the teaching quality of teachers. This approach is worth promoting and spreading out.

(3)The practice of the construction and reform of advanced mathematics in our school shows that the quality courses created by this project and the condensed materials have a great and widespread impact, which has great application and value.

For example: In the process of the creation "advanced mathematics teaching quality engineering". We publish the excellent teaching materials, a new theory of probability and mathematical statistics, which were wrote concisely by the teachers in our school. Due to the popularity and praise of the readers and institutions, it has been printed 17 times in the last few years, printing up to 100,000 copies to meet the needs of readers.

(4)The innovative quality education and its intensive development enabled the students in our college to gain good results in the national university modeling competition, which has far surpassed many other important, first-class universities. For example, in the first competition in 2008, seven teams from our 12 teams won the first prize in fujian division, the second prize was six, and the winning rate was $60 \%$.It is the only independent college in the province that has achieved fruitful results in the university. After that, our college has achieved 
outstanding results every year. In 2010, the national college mathematical modeling contest, our school has seven of eight teams, which won the national award 1 second, was awarded the first prize for fujian division 3 items, 3 items second prize, award rate is as high as $87.5 \%$, became second only to the second of xiamen university in the province's colleges and universities. In 2011,our school to compete for high level number again hit a new high performance awards, 10 teams in our school won the first prize in the national total 1 item, the national second prize 1 ,second prize of fujian division 3 items.

At present, the teaching reform of advanced education continues to move on, and the mode of talent training has been explored. It is time to call for creating high quality courses, deepening the course construction and reform of advanced mathematics, cultivating first-class science and technology talents with comprehensive innovation quality in our higher education in the new century. And it is also the future directions of our main job. In the face of the glorious and arduous task, we are determined to have the courage to explore bold practice, dare to break through, to change conventional educational ideas, deepening educational reform, to work hard to cultivate more excellent talents in higher education for our country.

\section{REFERENCES}

[1] Liu Yan Dong. Deepen the reform of higher education, in order to improve the quality as the core of connotative development road[J]. Qiu Shi,2012,(10):3

[2] Ministry of Education. Some opinions on further deepening undergraduate teaching reform and improving education quality comprehensively[R].Teach high.[2017]2 files.

[3] Zhong Bing Lin. Promote the integration of university science and education and try to cultivate innovative talents[J].Chinese university teaching,2012.(5):6.

[4] Ge Wen Jie. Taking "quality and innovation" as core, deepening curriculum teaching reform and construction[J].Chinese university teaching, 2013,(7):36-38.

[5] Wu Di.The development and thinking of education curriculum system of university entrepreneurship[J]. Contemporary education BBS,2011(8).

[6] Zhu Qing Shi. Reform and development of education in the $21 \mathrm{st}$ century[M]. BeiJing:Higher education press,2002.

[7] Zhong Bing Lin. The reform of talent training mode is the core of the connotation construction of advanced education[J].Chinese university teaching,2013,(11)71-76.

[8] Xiao Xiaonan. Micro-thinking and macro development in university mathematics teaching[J]. Chinese university teaching,2013,(7):46-48.

[9] Chen Jin Jiang. Research on the operation mode of the elite college of Chinese universities [D]. WuHan: Huazhong university of science and technology, education science graduate school,2010:73.

[10] Liu Xian Jun. On the normalization of research about higher education[J]. Higher education research,2013,(11)42-48.

[11] Gong Xiu Min. Break the traditional teaching mode Cultivate talents of international vision[J]. Journal of Beijing union university,2002(49).

[12] Pan Mao Yuan. Book review about "Learning style and independent study of college students"[J].Journal of xi 'an jiaotong university (social science news),2004,24(4):95-96.

[13] Lu Gen Shu. Classroom learning environment, learning style and development of college students $[\mathrm{J}]$. Fudan university education BBS, 2012,(4):46-55.

[14] Wang Jian. The dilemma of class[J]. Contemporary education and culture,2013,(5):60-63.

[15] Lu Gen Shu, Cheng Guang Xu, Yang Zhao Fang. University classroom learning environment theory $[\mathrm{M}]$. XiAn: $\mathrm{Xi}$ 'an jiaotong university press, 2010

[16] Wang Hui, Hua Guo Dong. On the value orientation of differential teaching [J]. Education research,2004,(11):41.

[17] Sun Yuan Tao, Li Ru Mi. The integrated structure of teaching and learning [J]. Teaching comments, 1999,(6):52.

[18] Pan Yun He, Lu Yong Xiang. etc. The exploration and practice of cultivating innovative talents for 20 years $[\mathrm{J}]$. Chinese university mathematics,2005,(11):21-24 